\title{
TYPHOID SPINE IN A NIGERIAN WITH SICKLE HAEMOGLOBIN
}

\author{
Geoffrey F. WALKer, London, England \\ From the Department of Surgery, University College, Ibadan, Nigeria
}

Spondylitis has been recognised as a complication of typhoid fever for eighty years but is now becoming increasingly rare in the more developed countries. This paper records a case seen recently in Nigeria. The patient also had sickle cell trait, and the possible significance of this finding is discussed.

\section{CASE REPORT}

A Yoruba schoolboy of sixteen was first seen in April 1962, having suffered from fever and pain in the low back and the left hip for three weeks. He was thin but did not look ill. He was able to stand unaided, but his back had lost the normal lumbar curve and was held rigid. Percussion of the lumbo-sacral area caused pain and the erector spinae muscles were tender.

Three weeks later the pain had become very severe and completely prevented him from walking. Radiographs revealed slight diminution of the L.4-L.5 disc space with a suspicion of early bridging (Fig. 1). A diagnosis of acute osteomyelitis of the spine was made. He was

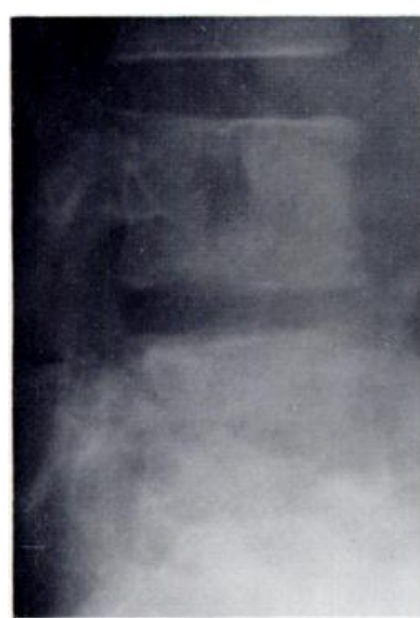

FiG. 1

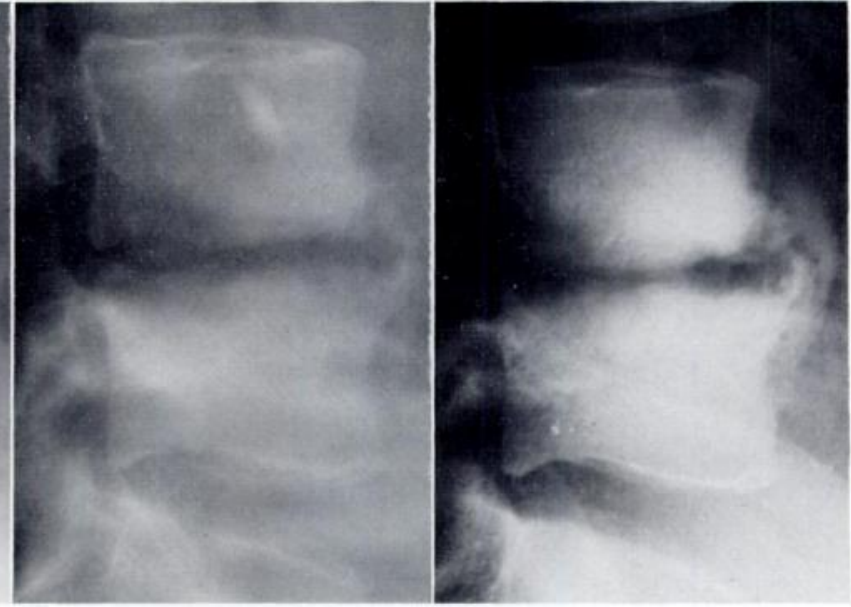

FIG. 2
FIG. 3

Figure 1-Radiograph on admission. Slight narrowing of the L.4-L.5 disc space. Figure 2-Six weeks later. Note further diminution of the disc space with involvement of the vertebral bodies and anterior bridging. Figure 3-Ten weeks after admission. Anterior fusion is occurring between the bodies of L.4 and L.5.

admitted and, even though no proven case of staphylococcal infection of the spine had yet been seen at University College Hospital, the staphylococcus at this stage seemed the most likely pathogen, and penicillin and streptomycin were given. To establish a definite diagnosis, a needle was inserted into the L.4-L.5 disc by the right postero-lateral route under radiographic control using an image intensifier coupled to closed circuit television. Very little fluid was aspirated, but salmonella typhi was cultured from the needle and syringe. Typhoid infection was also confirmed by agglutination reactions (Table I), and accordingly chloramphenicol (250 milligrams six hourly) was substituted for penicillin and streptomycin and was continued for six weeks. After five weeks the patient felt much better and suffered only slight back pain. The temperature, which on admission had reached 100 degrees Fahrenheit (37.7 degrees 
Centigrade) settled within four weeks. The pulse rate remained consistently between 90 and 100 beats per minute.

Other investigations-Haemoglobin electrophoresis showed haemoglobin pattern AS. The Heaf test was $1+$. The erythrocyte sedimentation rate was 83 millimetres in the first hour (Westergren). The white blood count two weeks before admission showed: total cells 11,800 per cubic millimetre (polymorphs 47 per cent, eosinophils 33 per cent*, lymphocytes 18 per cent, monocytes 2 per cent). Platelets were plentiful. Sickling was present.

Progress-All the symptoms subsided and within three months the spine appeared normal on examination. Nevertheless, serial radiographs showed increasing narrowing of the L.4-L.5 disc space with sclerosis of the bodies and anterior bridging (Figs. 2 and 3).

When questioned further the patient asserted that he had never been ill before, apart from an attack of jaundice shortly before his admission. He had then noticed that his urine was dark and his eyes were yellow for about four weeks. He had received native medicine and had remained at home during this time. In retrospect this was probably an example of one of the many presentations of typhoid fever in West Africans.

The blood continued to agglutinate suspensions of salmonella typhi (Table I). The white cells never exceeded 11,800 per cubic millimetre and a relative lymphocytosis did not occur.

TABLE I

Serial Agglutination Tests Against Five laboratory Suspensions

\begin{tabular}{|c|c|c|c|c|c|}
\hline Date & $\begin{array}{c}\text { Salmonella } \\
\text { typhi } \\
D(9,12)\end{array}$ & $\begin{array}{c}\text { Salmonella } \\
\text { typhi } \\
\text { d (H) }\end{array}$ & $\underset{\substack{\text { Salmonella } \\
\text { typhi }}}{\text { Va }}$ & $\begin{array}{c}\text { Salmonella } \\
\text { paratyphi } \\
(\mathbf{1 , 4 , 5 , 1 2 )}\end{array}$ & $\begin{array}{c}\text { Salmonella } \\
\text { London } \\
(\mathbf{3}, \mathbf{1 0})\end{array}$ \\
\hline May 25 & $1 / 320$ & $1 / 2,560$ & $1 / 160$ & $1 / 160$ & - \\
\hline June 8 & 1640 & $1 / 1,280$ & $1 / 320$ & $1 / 80$ & $1 / 160$ \\
\hline June 13 & $1 / 640$ & $1 / 1,280$ & - & $1 / 80$ & - \\
\hline June 21 & $1 / 640$ & $1 / 1,280$ & - & - & - \\
\hline July 10 & $1 / 320$ & $1 / 2,560$ & $1 / 80$ & $1 / 80$ & - \\
\hline July 26 & $1 / 320$ & $1 / 2,560$ & - & - & $1 / 80$ \\
\hline August 28 & $1 / 320$ & $1 / 1,280$ & $1 / 80$ & - & - \\
\hline
\end{tabular}

The haemoglobin level remained between 11.5 and 14.5 grammes per 100 millilitres. Repeated attempts at blood, stool and urine culture consistently failed to grow either salmonella or any other pathogen. Three months after admission the erythrocyte sedimentation rate had fallen to 11 millimetres in the first hour and cholecystography revealed a normal functioning gall bladder.

\section{DISCUSSION}

Although Whitman (1930) mentioned a thesis by Maisonneuve on this subject in 1835, the clinical entity of " typhoid spine" was first established by Gibney in 1889. That the specific fevers, notably typhoid fever, could be complicated by osteitis or periostitis had been recorded earlier (Paget 1876, Keen 1877, Terrillon 1884, Jones 1887).

Osler in 1894 described two cases of typhoid spine but ascribed the pain to a neurosis. Many case reports followed (Lovett and Withington 1900, Cutler 1902, Lord 1902, Favre and Bovier 1913) and Lance (1911) added fifteen new cases to the eighty already reported. Murphy (1916) commented on 164 cases of periostitis and osteitis which occurred in 18,840 patients suffering from typhoid fever (an incidence of 0.82 per cent). Textbooks of orthopaedics

\footnotetext{
* A common finding in West Africans, and attributed to parasitic infestations.
} 
published during the next fourteen years contain references to typhoid spine (Jones and Lovett 1929, Whitman 1930). Albee in 1919 described the clinical picture and emphasised that the onset is during the early months of convalescence.

During the last thirty years reports of patients with confirmed typhoid spines are rare, and although this may be a result of the widespread appreciation of this condition, it is interesting to note that Huckstep (1962a and $b$ ) working with more than a thousand typhoid patients in East Africa only saw one probable case. There are, however, several descriptions of spinal lesions caused by salmonella other than salmonella typhi (Waaler 1935; Anchersen 1947; Rozansky, Ehrenfeld and Matoth 1948; Ralston 1955; Greenspan and Feinberg 1957; Massachusetts General Hospital 1958; Stenström 1958; Waisbren 1960), which often affected the second and third lumbar vertebrae.

Osteomyelitis due to salmonella (either typhoid or non-typhoid), while not very common, is also widely recognised and has been well documented (Ferrier 1952).

Association of salmonella bone infections with abnormal haemoglobins-The presence of sickle haemoglobin, found commonly in many negro races, has in the last few years been shown to bear a strong relation to salmonella bone and joint infections (Hodges, Holt, Jacox and Collins 1951; British Medical Journal 1957; Hook, Campbell, Weens and Cooper 1957; Roberts and Hilburg 1958; Hendrickse and Collard 1960). Patients with sickle cell anaemia (homozygous haemoglobin S disease or SS) are liable to develop infarcts of bone which frequently become infected with salmonella organisms. Similarly, patients with salmonella bone or joint infections are often found to have sickle cell anaemia (SS). A case of "typhoid spine" recently reported from Bamako in West Africa showed the heavy proportion of eighty sickle forms per 100 red cells, and was almost certainly an example of sickle cell anaemia (SS) complicated by salmonella osteomyelitis of the spine (Bourrel and Boissan 1961).

While there is no doubt of the relationship between homozygous haemoglobin $\mathrm{S}$ disease (SS) and salmonella bone infections, it is likely that the combination of sickle $\mathrm{S}$ and another abnormal haemoglobin $\mathrm{C}$, also found in West Africans and responsible for "sickle cell haemoglobin C" disease (SC), similarly predisposes to salmonella bone infections.

The combination of sickle $\mathrm{S}$ and normal adult $\mathrm{A}$ haemoglobin producing "sickle cell trait" (AS) has not previously been incriminated as a factor predisposing to salmonella bone infections (Watson-Williams 1962). The association in this patient of sickle cell trait with a typhoid spine is therefore of interest.

\section{TREATMENT}

Treatment of typhoid spines is eminently satisfactory, as the condition is largely selflimiting with spontaneous bony fusion of the affected vertebrae. Older writers refer to rest, immobilisation, relief of pain and application of counter irritants, while more recently typhoid osteomyelitis has been found to respond reasonably well to chloramphenicol and surgical intervention (Ferrier 1952). Chloramphenicol alone produced a rapid and dramatic relief from pain in our case. Reports of only two fatalities have been found in the literature; in both of these patients the typhoid spines were complicated by abscess formation and abdominal aneurysm (Miller 1954, Simon and Silver 1957).

\section{SUMMARY}

1. A proven case of typhoid spine in a patient with sickle cell trait (AS) is recorded. It responded well to conservative treatment with chloramphenicol.

2. The literature on typhoid spine is briefly reviewed and the relationship between salmonella osteomyelitis and sickle cell disease is discussed.

I wish to thank Dr Hugh Platt for assistance with the interpretation of the laboratory findings, Mr F. Speed for reproducing the radiographs, and Mr H. Jackson Burrows for his valuable advice. 


\section{REFERENCES}

Albee, F. H. (1919): Orthopedic and Reconstruction Surgery, p. 374. Philadelphia and London: W. B. Saunders. ANChersen, P. (1947): Spondylitt framkalt av salmonella paratyphi B. En oversifet og et tilfelle. Nordisk Medicin, 36, 2,019.

Bourrel, P., and Boissan, R. H. (1961): Un cas soudanais de spondylite typhique. Médecine Tropicale, $21,134$. British Medical Journal (1957): Sickle Cells and Salmonella. British Medical Journal, ii, 1,537.

Cutler, E. G. (1902): Typhoid Spine (spondylitis typhosa; perispondylitis typhosa). Boston Medical and Surgical Journal, 146, 687.

FaVre, M., and Bovier, L. (1913): Sur un cas de spondylite typhique. Lyon Médical, 120, 777.

Ferrier, J. (1952): Salm. typhi osteomyelitis. Report of a Case, with a Review of the Literature. British Medical Journal, ii, 318.

Gibney, V. P. (1889): The Typhoid Spine. Transactions of the American Orthopedic Association, 2, 19.

Greenspan, R. H., and Feinberg, S. B. (1957): Salmonella Bacteremia. A Case with Miliary Lung Lesions and Spondylitis. Radiology, 68, 860.

Hendrickse, R. G., and Collard, P. (1960): Salmonella Osteitis in Nigerian Children. Lancet, i, 80.

Hodges, F. J., Holt, J. F., Jacox, H. W., and Collins, V. P. (1951): The 1951 Year Book of Radiology, p. 88. Chicago: The Year Book Publishers, Inc.

Hook, E. W., Campbell, C. G., Weens, H. S., and Cooper, G. R. (1957): Salmonella Osteomyelitis in Patients with Sickle Cell Anaemia. New England Journal of Medicine, 257, 403.

Huckstep, R. L. (1962a): Personal communication.

HucksteP, R. L. (1962b): Typhoid Fever and Other Salmonella Infections. Edinburgh and London: E. \& S. Livingstone Ltd.

Jones, Sir R., and Lovett, R. W. (1929): Orthopedic Surgery. Second edition, p. 215. London: Oxford University Press.

Jones, T. (1887): Diseases of the Bones. Their Pathology, Diagnosis and Treatment. London: Smith, Elder \& Co. Manchester: Cornish.

Keen, W. W. (1877): The Toner Lecture-On the Surgical Complications and Sequels of the Continued Fevers. Smithsonian Miscellaneous Collections, 15, 40.

LanCE, M. (1911): La spondylite typhique. Gazette des Hopitaux Civils et Militaires, 1,018.

LORD, F. T. (1902): Analysis of Twenty-six Cases of Typhoid Spine. Boston Medical and Surgical Journal, $146,689$.

Lovett, R. W., and Withington, C. F. (1900): Typhoid Spine. Boston Medical and Surgical Journal, $142,317$.

Maisonneuve, J. G. (1835): Thèse, Paris.

Massachusetts General Hospital (1958): Case Records of the Massachusetts General Hospital. Weekly Clinicopathological Exercises. Case 44,012. New England Journal of Medicine, 258, 42.

Miller, A. A. (1954): Salmonella Dublin Osteomyelitis of the Spine. Report of a Fatal Case. British Medical Journal, i, 194.

Murphy, J. B. (1916): Bone and Joint Disease in Relation to Typhoid Fever. Surgery, Gynecology and Obstetrics, 23, 119.

Osler, W. (1894): On the Neurosis Following Enteric Fever, Known as " the Typhoid Spine." Johns Hopkins Hospital Reports, 4, 73.

Paget, Sir J. (1876): On Some of the Sequels of Typhoid Fever. St Bartholomew's Hospital Reports, $12,1$.

Ralston, E. L. (1955): Osteomyelitis of the Spine Due to Salmonella Cholerae Suis. Journal of Bone and Joint Surgery, 37-A, 580.

Roberts, A. R., and Hilburg, L. E. (1958): Sickle Cell Disease with Salmonella Osteomyelitis. Journal of Pediatrics, 52, 170.

Rozansky, R., Ehrenfeld, E. N., and Matoth, Y. (1948): Paratyphoid Osteomyelitis, Report of Two Cases. British Medical Journal, ii, 297.

Simon, S. D., and Silver, C. M. (1957): Salmonella Osteomyelitis. Report of Three Cases, One with Fatal Outcome and Autopsy. Journal of the International College of Surgeons, $28,197$.

Stenström, R. (1958): Spondylitis Caused by Salmonella Typhimurium. Acta Radiologica (Stockholm), 49, 355.

Terrillon, M. (1884): Des périostites consécutives à la fièvre typhöide. Progrès Médical, 12, 285.

WAALER, E. (1935): Infeksjon med bacillus paratyphus A komplisert med spondylitt. Norsk Magazin for Laegevidenskapen, 96, 1,051.

WaisBren, B. A. (1960): Pyogenic Osteomyelitis and Arthritis of the Spine Treated with Combinations of Antibiotics and Gamma Globulin. Journal of Bone and Joint Surgery, 42-A, 414.

Watson-Williams, E. J. (1962): Personal communication.

Whitman, R. (1930): A Treatise on Orthopaedic Surgery. Ninth edition, p. 119. London: Henry Kimpton.

Wigh, R., and Thompson, H. J., Jun. (1950): Cortical Fissuring in Osteomyelitis Complicating Sickle-cell Anemia. Radiology, 55, 553. 